\title{
Microbial Water Quality During the Northern Migration of Sandhill Cranes (Grus canadensis) at the Central Platte River, Nebraska
}

The central Platte River is an important resource in Nebraska. Its water flows among multiple channels and supports numerous beneficial uses such as drinking water, irrigation for agriculture, groundwater recharge, and recreational activities. One of the most popular recreational activities on the central Platte River in Nebraska is bird watching during the spring migration period.

The central Platte River valley is an important stopover for migratory waterfowl and cranes, such as the Whooping (Grus americana) and Sandhill Cranes (Grus canadensis), in their annual northward traversal of the Central Flyway. From late February to early April, approximately 600,000 Sandhill Cranes stop along the central Platte River, building up their fat reserves and absorbing nutrients vital to their survival through the nesting season. Millions of waterfowl, shorebirds, and other species also migrate northward through the area every spring (Buckley, 2011).

Waterfowl, cranes, and other migratory birds moving across international and intercontinental borders may provide long-range transportation for any microbial pathogen they harbor, particularly through the spread of feces (Alderisio and Deluca, 1999). Pathogens carried by waterfowl that have been determined to affect humans and agriculture include avian influenza, Escherichia coli (E. coli), Cryptosporidium, Giardia, Campylobacter, and Legionella (Graczyk and others, 2008; Clark, 2003). Pathogens can be spread by these migratory birds through contaminated air and water (Broman and others, 2000), and rivers may serve as a pathway for transmission of waterborne diseases to humans and other animals. The central Platte River valley is a bottleneck section of the Central Flyway. Dense groupings of Sandhill Cranes can be found roosting in shallow water around sandbars in an 80-mile stretch of the Platte River between Overton and Grand Island, Nebraska.

The objectives of the study were to collect a baseline dataset of avian pathogen concentrations in the Platte River, and to compare avian pathogen concentrations of the most commonly used roosting reach in the Central Platte to help determine the effect of migratory birds on waterborne pathogen

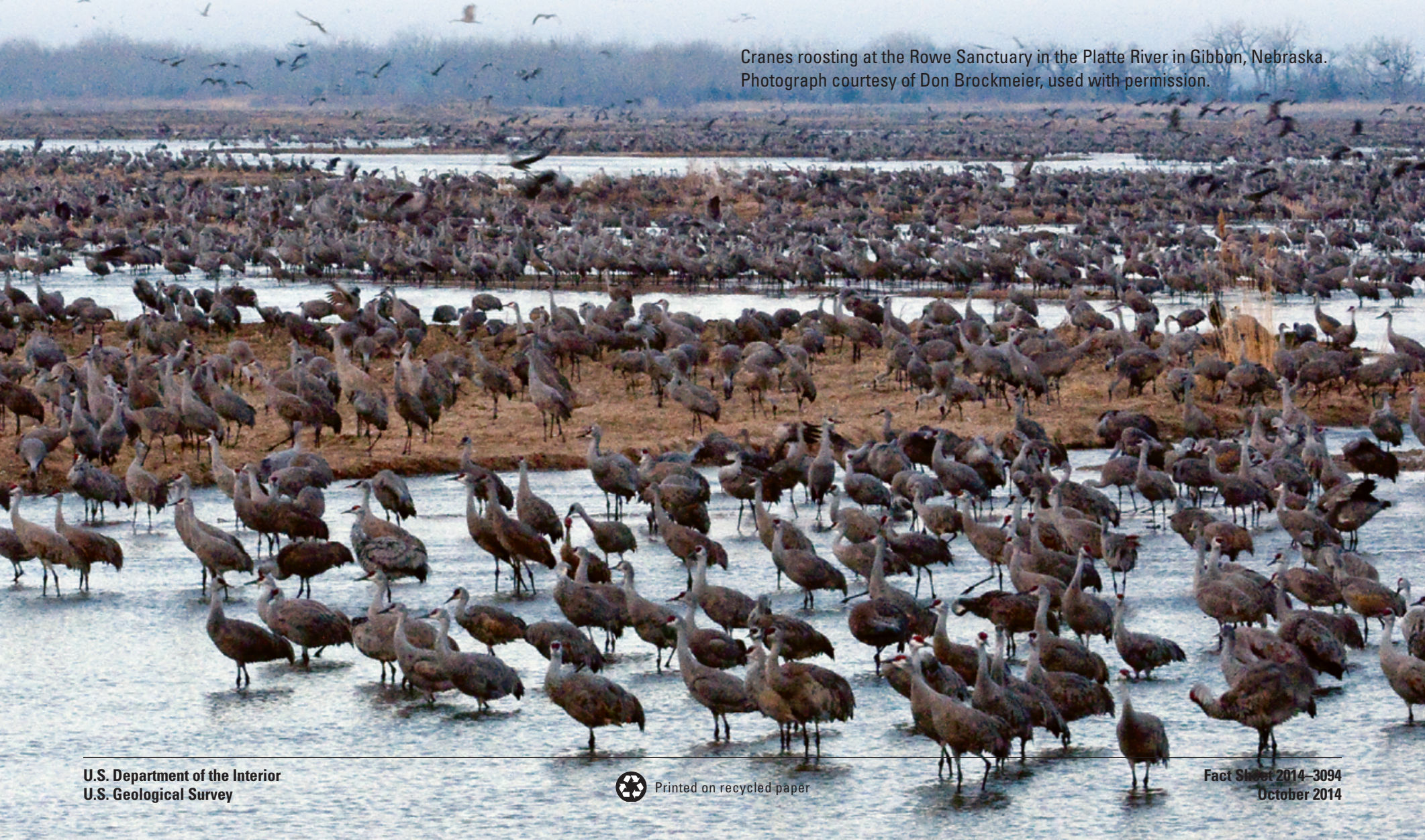




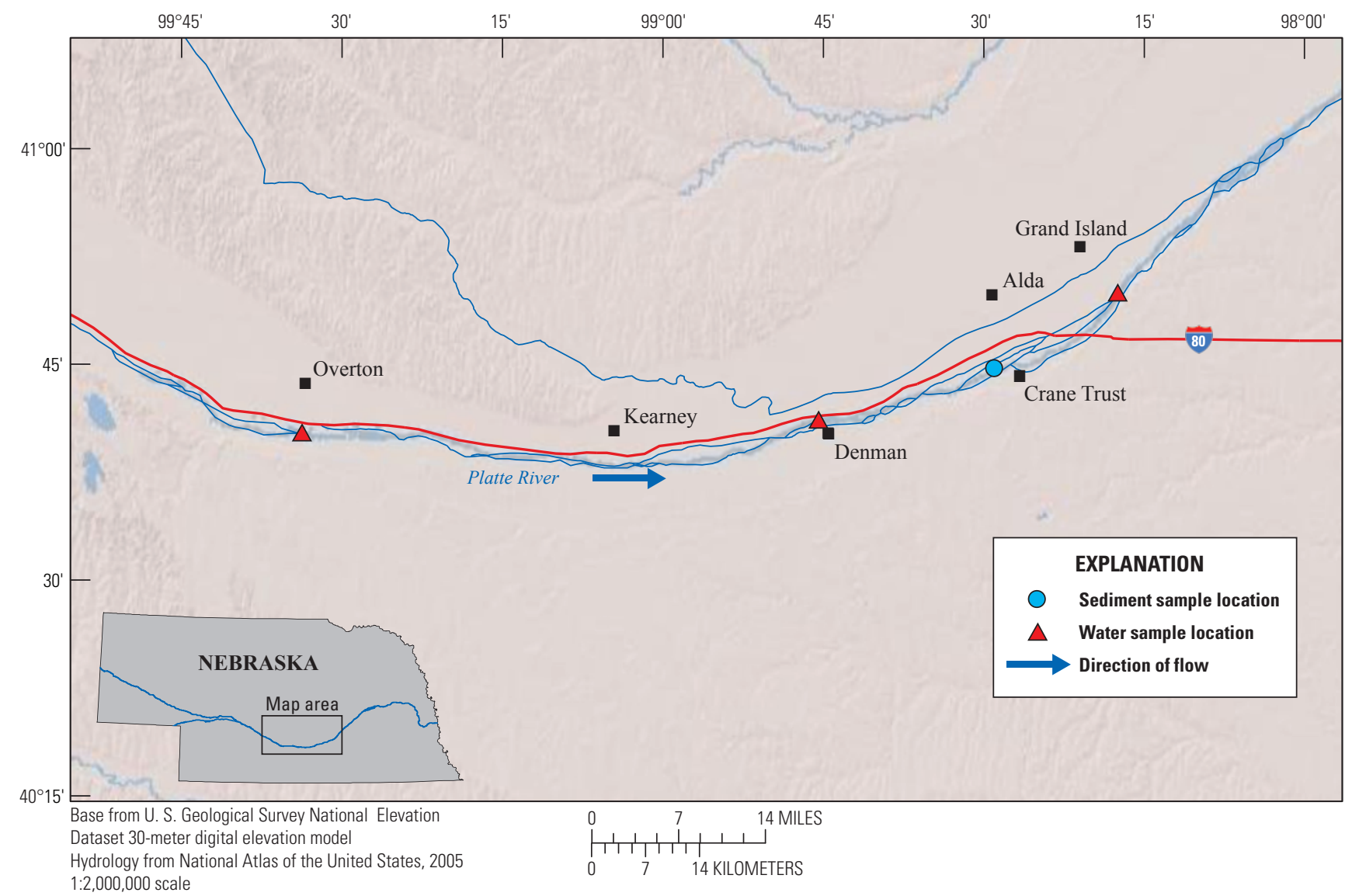

Figure 1. Location of study area and sampling locations on the Platte River, central Nebraska (Vogel and others, 2013).

concentrations. Water, sediment, and fecal samples were collected between February and April 2009 and 2010 by the Nebraska Water Science Center. The sampling period coincided with the spring migration season of Sandhill Cranes and other waterfowl in the Central Flyway of North America. Water and sediment samples were collected upstream from, in the middle of, and downstream from the densest Sandhill Crane roosting locations. Water samples were collected near Overton, Nebr. (the most upstream sampling location); Denman, Nebr. (located mid-reach); and Grand Island, Nebr. (the most downstream sampling location) (fig. 1). Riverbed sediment samples were collected from the Platte River near The Crane Trust visitor center in locations where the Sandhill Cranes were known to have roosted the night before. Fecal samples were collected from various areas where the targeted cranes and waterfowl were gathering.

The samples were analyzed for avian influenza, E. coli, Enterococci, Cryptosporidium, Giardia, Campylobacter, and Legionella. Analysis of these samples indicated that peak $E$. coli and Campylobacter densities were concurrent with the peak population of migrating Sandhill Cranes as indicated from bird counts (Buckley, 2011). The densities of sampled constituents were also higher during the night, when cranes would have been roosting in the river, than during daylight hours (fig. 2).

The Platte River on April 6, 2009, as seen from Crane Trust near Alda, Nebraska. Photograph by Matt Moser, U.S. Geological Survey.
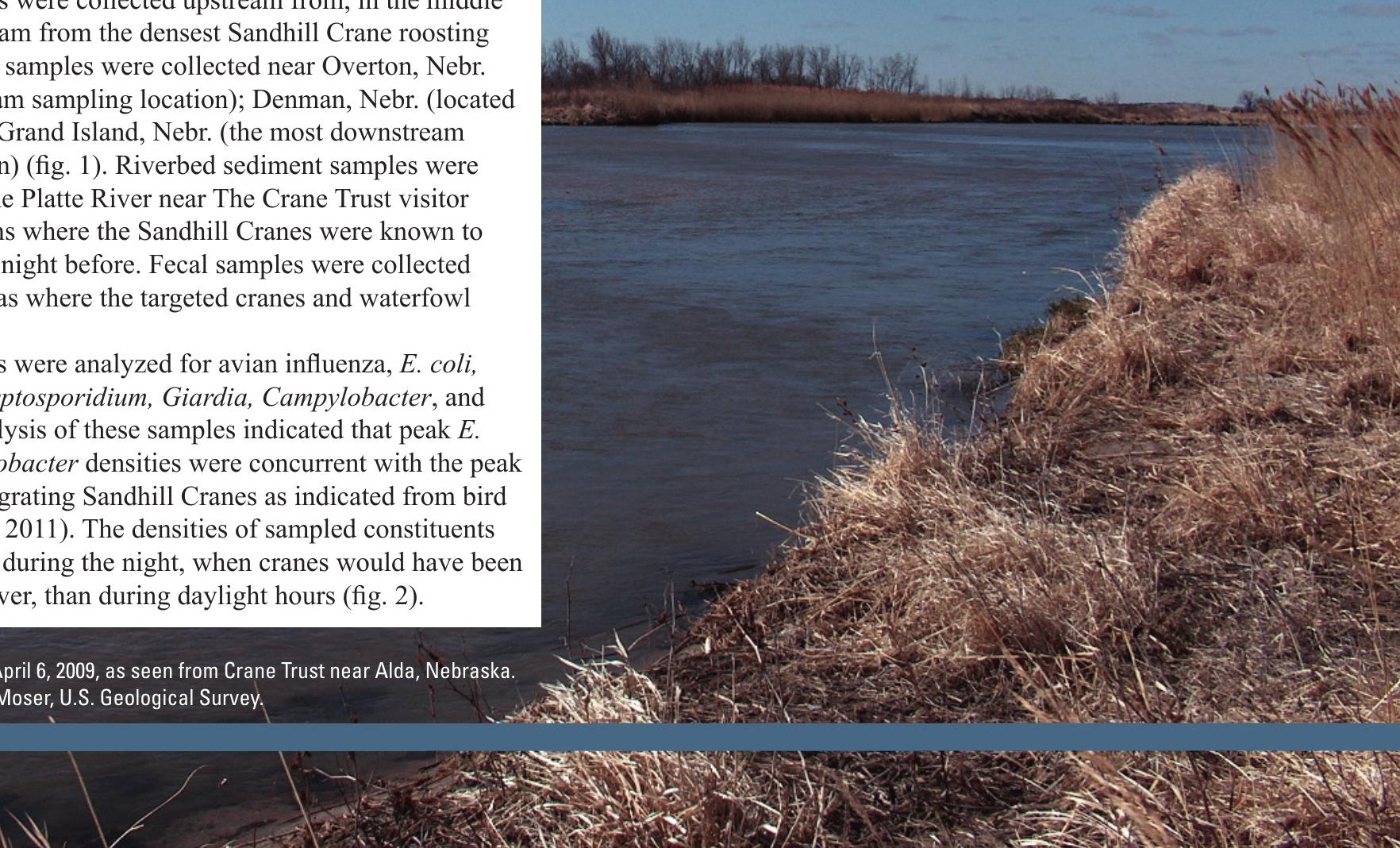
Numerically, migrating Sandhill Cranes contribute a large excreta mass each spring, with stopover by more than 600,000 birds on the central Platte River. The data from this study indicated that fecal indicator bacteria and, in some cases, potential pathogens relevant to humans and agriculture were present in 2009 and 2010. Other conclusions from this study included the following (Vogel and others, 2013):

- Within river-bottom sediment at a crane roosting site, Enterococci and the crane-specific Bacteroidetes marker were detected during the migration season but not during the nonmigration season;

- Bacterial densities in sampled river water were significantly higher (with 95-percent confidence for $E$. coli and with 90-percent confidence for Enterococci) at the downstream sites during the migration season than at the upstream site, and higher than at all sites during the nonmigration season;

- Diurnal studies at the most downstream site in 2010 indicated that densities of both E. coli and Enterococci were greater in water samples collected between 2230 and 1100 hours, which is reflective of the cranes' night roosting period plus bacterial travel time in the stream from roosting site to sampling site;

- The crane-specific Bacteroidetes marker in water samples was amplified only for samples collected from the two downstream sites during the migration season, but not for samples from the upstream site or for any site during the nonmigration season;

- Campylobacter jejuni seems to be a prevalent pathogen excreted by Sandhill Cranes and, along with Giardia (detected in Sandhill Crane feces but not goose feces), was only detected in water samples during the migration period during 2009 when there was no substantial concurrent rainfall or snowmelt runoff.

Results also indicated that several types of fecal-indicator bacteria and a range of viral, protozoan, and bacterial pathogens were present in Sandhill Crane excreta, and occurred at significantly higher frequency and densities in water and sediments when the cranes were present, particularly during evening roosts within the Platte River channel. The presence of these pathogens in the river water is a source for exposure to other users of untreated water, potentially local human recreationists, livestock, and wildlife.

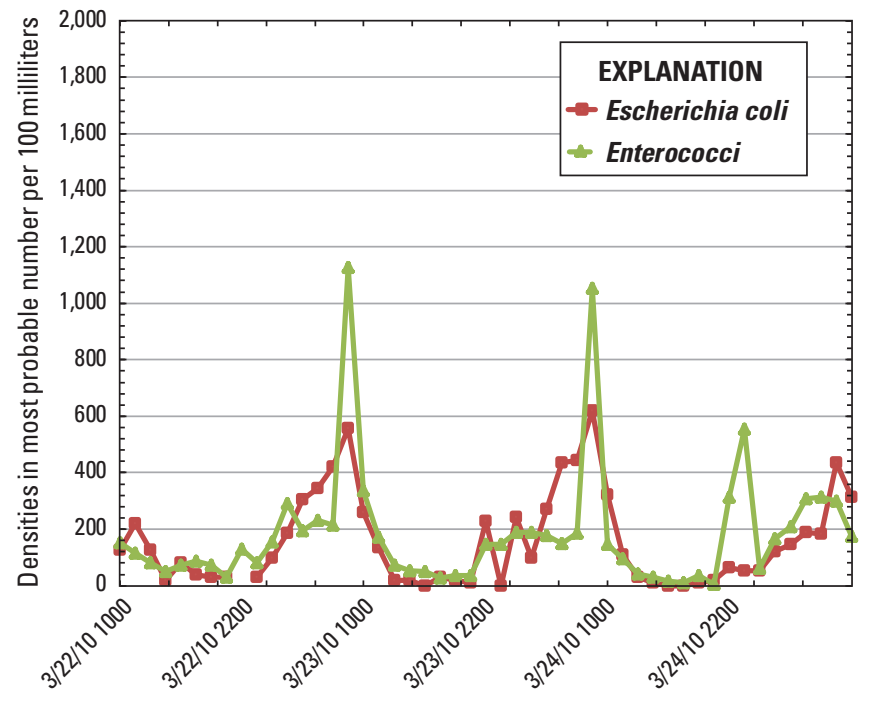

Month/day/year (1000, in 24-hour time)

Figure 2. Escherichia coli and Enterococci densities (in most probable number per 100 milliliters) during March 22-25, 2010, near Grand Island, Nebraska (Vogel and others, 2013).

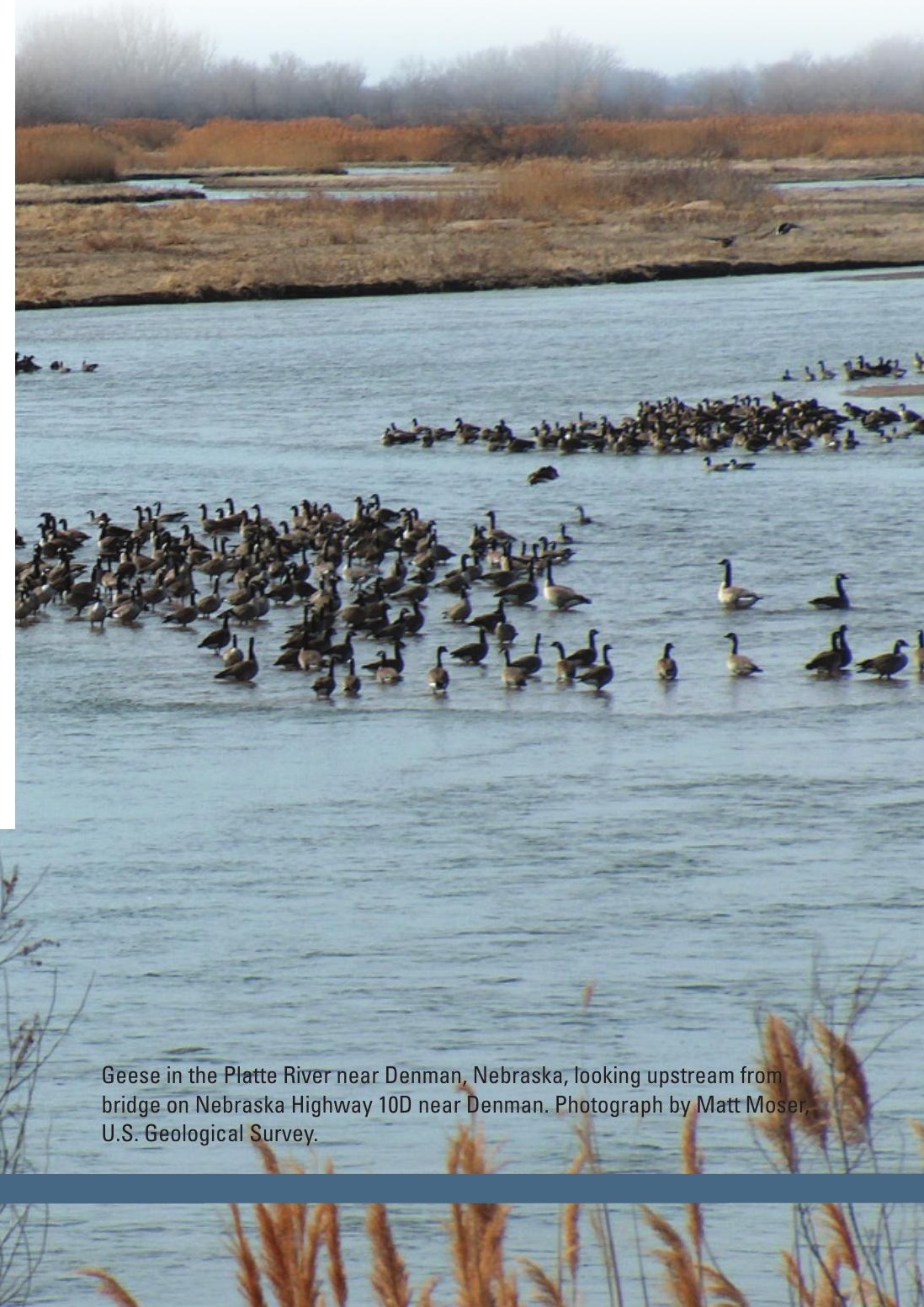




\section{References Cited:}

Alderisio, K.A., and DeLuca, N., 1999, Seasonal enumeration of fecal coliform bacteria from the feces of ring-billed gulls (Larus delawarensis) and Canada geese (Branta canadensis): Applied Environmental Microbiology, v. 65, p. 5628-5630.

Broman, T.B., Bergstrom, S., On, S.L.W., Palmgren, H., McCafferty, D.J., Sellin, M., and Olsen, B., 2000, Isolation and characterization of Campylobacter jejuni subspecies 25 jejuni strains from Macaroni Penguins (Eudyptes chrysolophus) in sub-Antarctica: Applied Environmental Microbiology, v. 66, p. $449-452$.

Bu $\mathrm{Bu}$

uckley, T.J., 2011, Habitat use and abundance patterns of Sandhill Cranes in the central Platte River valley, Nebraska, 2003-2010: Lincoln, University of Nebraska, Dissertations \&

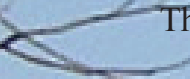

Theses in Natural Resources, Paper 38, 134 p.

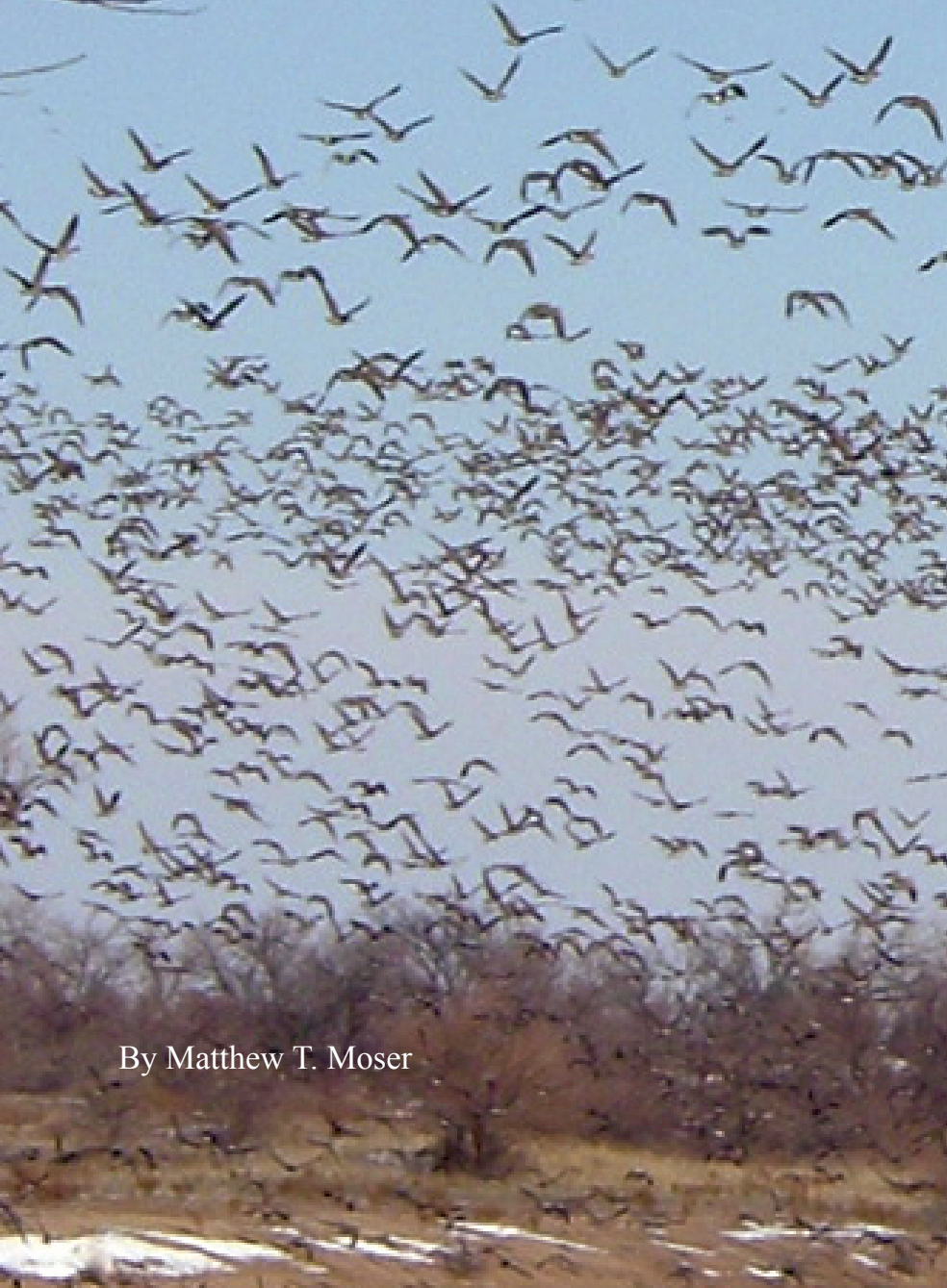

For further information contact:

Director

Nebraska Water Science Center

U.S. Geological Survey

5231 South 19 th Street

Lincoln, NE 68512-1271

dc_ne@usgs.gov

http://ne.water.usgs.gov/

Clark, L., 2003, A review of pathogens of agricultural and human health interest found in Canada Geese, in Fagerstone, K. A. \& Winters, G. W. eds., Proceedings of the 10th Wildlife

Damage Management Conference: Fort Collins, Colorado, Paper 205

Graczyk, T.K., Majewska, A.C., and Schwab, K.J., 2008, The role of birds in dissemination of human waterborne enteropathogens: Trends in Parasitology, v. 24, no. 2, p. 55-59.

Vogel, J.R., Griffin, D.W., Ip, H.S., Ashbolt, N.J., Moser, M.T., Lu, Jingrang, Beitz, M.K., Ryu, Hodon, and Santo Domingo, J.W., 2013, Impacts of migratory Sandhill Cranes (Grus canadensis) on microbial water quality in the central Platte River, Nebraska, USA: Water Air Soil Pollution, v. 224, p. 1576
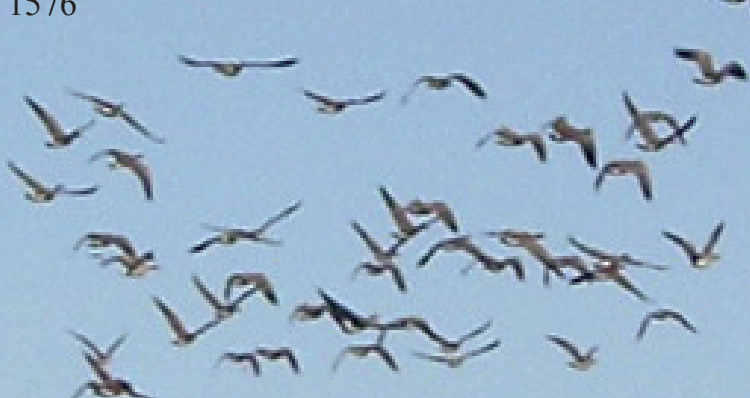

HP

Q1 $-70 \%$
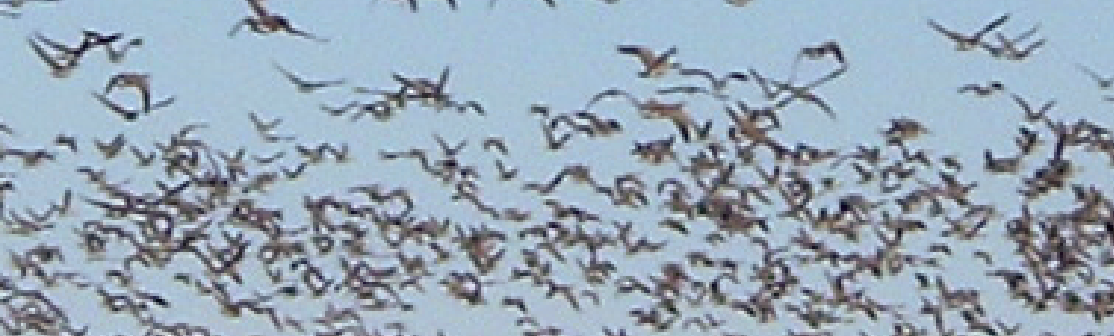
Q4

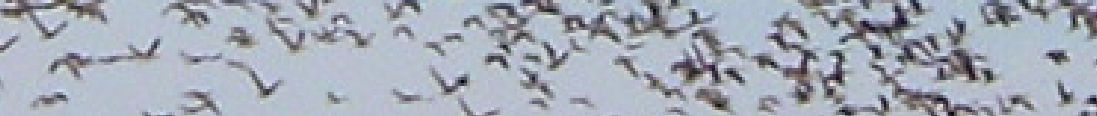

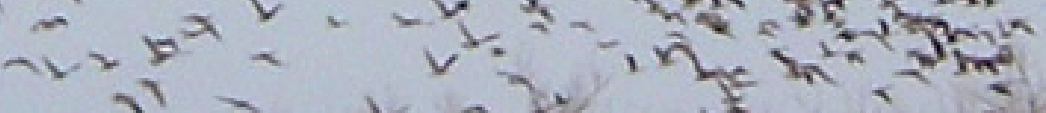

